\title{
IMPROVING SAFETY BEHAVIOR IN AIRPORT CARGO WAREHOUSE
}

\author{
Dinar Dewi Kania', Dian Artanti Arubusman², Eko Probo D. \\ Warpani $^{3}$, Oce Prasetya ${ }^{4}$
}

1. STMT Trisakti, 2. STMT Trisakti, 3. STMT Trisakti, 4. STMT Trisakti

$\triangle$ corresponding author: dinar.insists@gmail.com

\begin{abstract}
The aim of this research is to identify the risk of the job at The SoekarnoHatta International Airport cargo warehouse and how to improve the safety behavior. The research used descriptive qualitative research and the risk assessment was employed to identify the highest risk of the job. The data obtained through observation on Focus Group Discussion (FGD), in-depth interview, and questioner. The risk level of activities in the outbound and inbound warehouses is essentially similar, but the risk in the inbound warehouses have a higher risk level than outbound warehouses. Risk control measures used to reduce the level of risk in the outbound and inbound warehouses are more of an administrative control and increased awareness of workers in using personal protective equipment (PPE) through active caring behavior.
\end{abstract}

Keywords: safety behavior, risk assessment, cargo, airport warehouse, behaviour-based safety

\section{Introduction}

The total number of accidents in Indonesia each year has increased, especially the increase of serious accident in the workplace (www.bpjsketenagakerjaan.go.id). The International Labor Organization (ILO) reported that every year there are more than 250 million accidents in the workplace and over 160 million workers become ill from hazards. While there are about 1.2 million workers died from accidents and illness at work. It is estimated that annual losses from work-related accidents and occupational diseases in some countries have reached $4 \%$ of Gross National Product(International Labour Organization, 2013).

The air transportation industry is inseparable from occupational health and safety issues. Unlike other industries, the occupational health and safety of the air transport company, has a direct impact on aviation safety because safety is the main product of transportation service. The efforts to improve safety management system should become a major concern of stakeholders of air transport services companies due to the factor of the highest accidents 
in Indonesia that is still dominated by the human factor $(67.12 \%)$ while the technical factor contributes $15.75 \%$ and the environmental factor of $12.33 \%$. The facility factor contributes only $4.79 \%$ (Komisi Nasional Keselamatan Transportasi, 2016).

The Safety Management System (SMS) must be built or developed based on risk identification and hazard in operational activities because good SMS should be risk-based. From a preventive perspective, if risks can be identified before serious failures occur, then incidents will be suppressed (Lee, 2006). Risk-prevention and reduction measures should use methodologies that include interdisciplinary measures such as assessing and resolving critical designs, the environment and process aspects, as well as the social and cultural dynamics (Cecchini, Bedini, Mosetti, Marino, \& Stasi, 2017).

Several studies of workers' perceptions of risk revealed that there was a variant in workers' understanding due to lack of communication or insufficient knowledge about job risks. Therefore, risk assessment is an important tool for ensuring proper understanding of risk. However, risk assessment does not provide assurance that the associated personnel has gained a good understanding of risk (Veland \& Aven, 2015). To reduce the work accident, it is necessary to control the risk factor through efforts to reduce the accident rate by controlling the risk factor through appropriate intervention model and relate to each industry type (Riyadina, 2007).

The research related to risk assessment in the air transportation industry, especially in airport cargo warehouse, is rare compared to mining or construction industry. Some previous research found were study on-ramp handling risk analysis at Halim Perdana Kusuma Jakarta Airport (Sari \& Artanti, 2015), Analysis of Occupational Safety and Health (K3) On Cargo Handling at Soekarno Hatta International Airport(Kania, Hanifah, \& Probo, 2016), Influence of Health and Safety Implementation on Employee AccidentInfluence of Health and Safety Implementation on Employee Accident(Agushinta, Anggun, \& Wijaya, 2016), The effect of training and occupational safety health on the performance of employees of the space services pt Jasa Angkasa Semesta(Susanthi \& Seruni, 2016), quarantine 
and sanitary risk on Low-Cost Carrier (LCC) from Southeast Asia at Qingdao Airport (Hou, 2016), The Implementation of Safety Management System (SMS) and The Competence of Traffic Flight Controller(Melissa et al., 2017) the risk of plane crashes from bird attacks (DeVault, Blackwell, Seamans, \& Jerrold, 2016), seismic hazards at Nepal Airport(Gautam, 2015), and some associated airport risks to terrorist acts, Stewart, Mark; Mueller (2013), Stewart, Mark; Mueller (2014), Shafieezadeh, Abdollah; Cha, Eun J; Ellingwood (2015).

The purpose of this writing is to identify the risks of work in the warehouse cargo of Soekarno Hatta International Airport and how to develop safety behavior. Some of activities in the build-up or break down process at the airport cargo warehouse, such as lifting, moving, inserting, and sorting items have potential high risk because serious injuries or accidents can occur frequently. Moreover, this process sometimes executed without reference to the user manual or (SOP), coupled with the lack of knowledge of the workers. The activities in the warehouse, if not properly managed, will become hazard and pose a risk of a work accident.

Risk Management is an essential feature for the Safety Management System (SMS), as well as Occupational Health and Safety Management System, Environment Management System, etc. If SMS operates independently from these other management systems, it tends to focus solely on safety risks without understanding the nature of the quality, security or environmental threats to the organization (International Civil Aviation Organization, 2013).

Daily risks ranges from a variety of factors. It might be the result of predetermined conditions such as biological factors. One substantial source of risk stems from the unsafe behavior of the workers(Ostrowska \& Mazur, 2015). The presence of good safety behavior does reflect compliance with safety, but safety issues cannot be effectively addressed without the intervention of corporate leaders with certain behavioral patterns as important criteria to change employee behaviour (Zin \& Ismail, 2012). 
Risk assessment is an evaluation of the likelihood that a potential hazard will actually cause harm, which also taking into account the frequency of exposure and severity of outcomes. The types of risk assessment are as follows; 1) those for large-scale complex hazards that required quantitative risk assessment (QRA); 2) those specifically required by legislation; 3) assessments specifically required or implied by legislation for a wide range activity; 4) assessment of behavioral risk for each individual job(Cooper, 2001). The purpose of risk identification is to assess all matters in the workplace that are hazardous and measure whether the company has taken adequate precautions or needs to be improved.

\section{Method}

This study was conducted by identifying the hazards and risks, then analyzed by qualitative method refers to the Australian / New Zealand Standard or AS / NZS 4360: 2004 standard. With this method, the risk acceptance judgment can be incorporated in probability-based risk matrices(Veland \& Aven, 2015).

The formula to determine the level of risk is:

Risk $=\mathrm{f}$ (consequences, likelihood $)$ or Risk $=$ consequences $\mathrm{x}$ likelihood

(Cooper, 2001)

The determination of likelihood criteria and the consequence were obtained from observation at Soekarno Hatta International Airport outbound and inbound warehouses, conducting in-depth interviews, questionnaires, and Focus Group Discussion (FGD) with warehouse employees, supervisors, and management. We also employed the triangulation method to validate the data obtained. Risk identification obtained from past (data) experiences, using checklists, through brainstorming, using flowcharts, system analysis, scenario analysis, and engineering systems. The likelihood is a qualitative image of probability or frequency, whereas consequences are the result of an 
occurrence that is expressed qualitatively or quantitatively in the form of injury, loss, or gain.

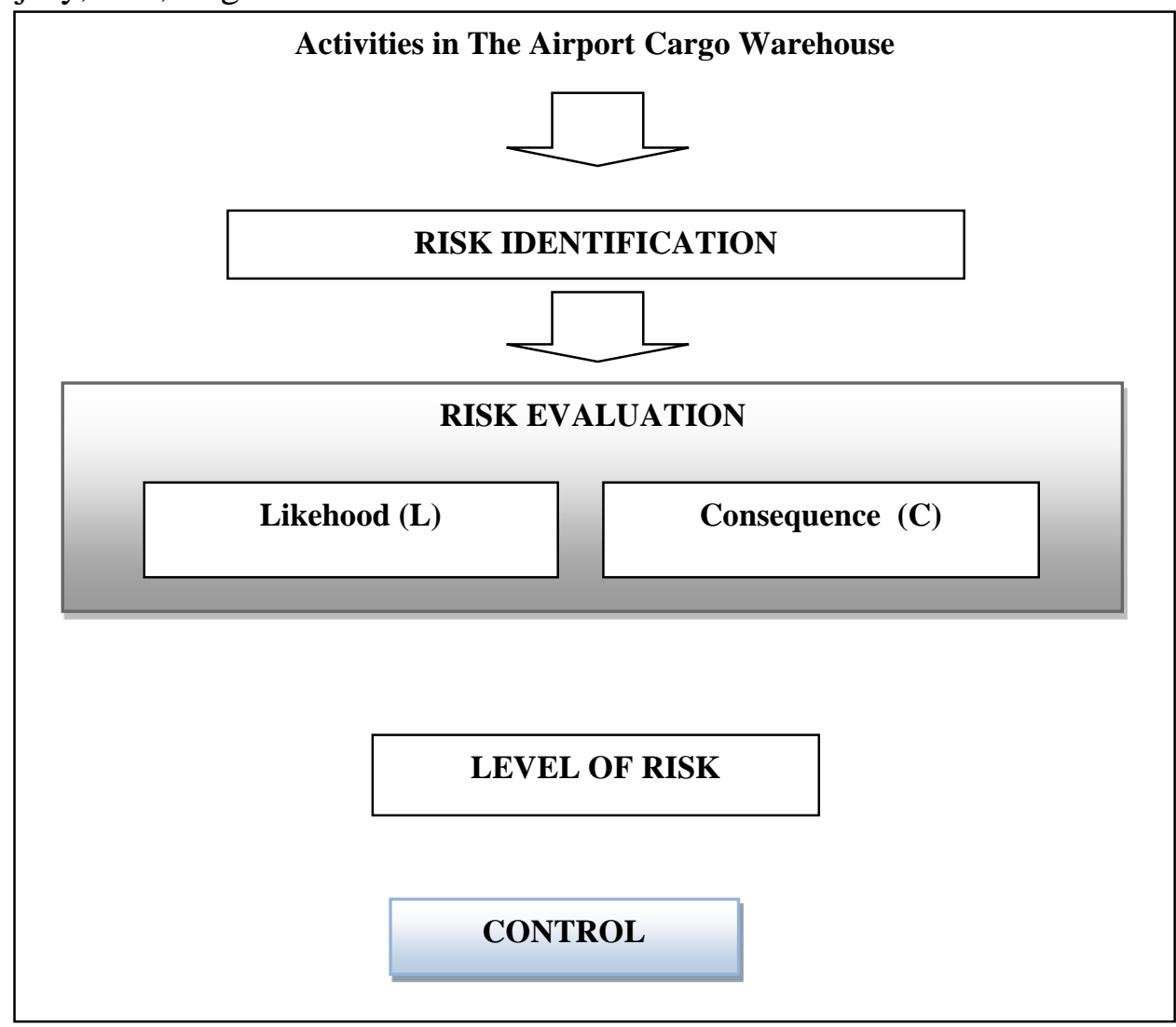

Figure 1. Steps of Risk Assessment in Airport Cargo Warehouse

\section{Results and Discussion}

1.The level of risks at the airport cargo warehouses

The cargo warehouses at Soekarno-Hatta International Airport store various types of goods and sizes. One of the risks encountered by workers is the exposure of chemicals or hazardous materials when in case of goods packaging broken. Hazardous materials or chemicals fall into the category of dangerous goods consisting of 9 classes. The hazards contained in dangerous goods can possibly injure the workers, pollute the environment, damage equipment, as well as damage other cargo. However, from the analysis, the risk of chemicals exposure in the cargo warehouse turned out to be a medium risk. From the interviews and observations data, the incidence rate of dangerous chemicals or dangerous goods in the airport cargo warehouse was 
rare. The result of risk analysis shows, the level of extreme and high risk at work in outbound and inbound cargo warehouse are as follows:

Table 1. Risk Level Matrix in The Cargo Outbound Warehouse

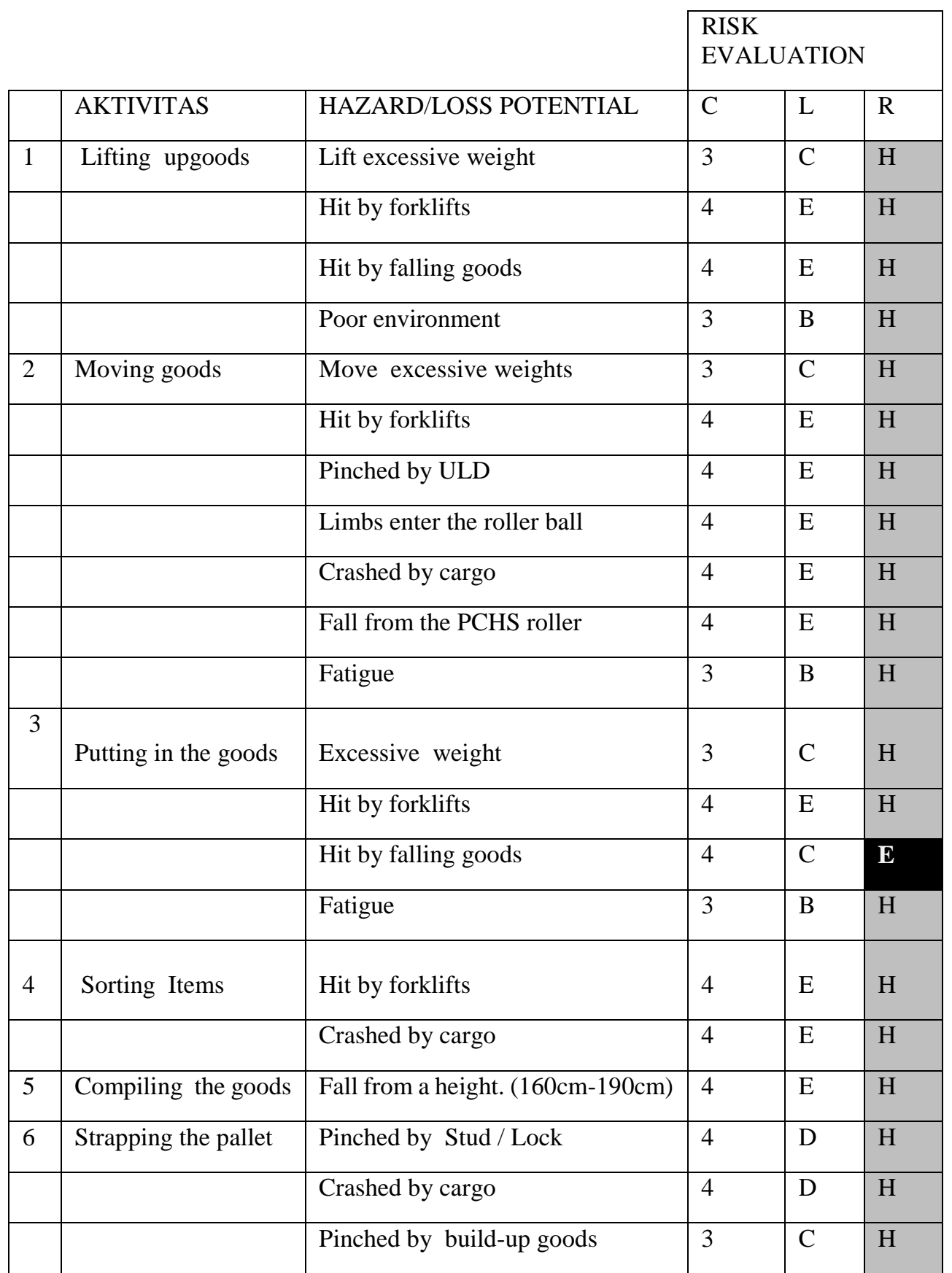

The extreme risk (E) in the outbound cargo warehouse is hit by the falling goods on the job of putting in the goods. The extreme risk $(\mathrm{E})$ to the worker means that the risk may cause permanent disability or even death. The extreme risk is also interpreted that it possibly causes severe and permanent 
damage to the cargo or goods. The high $(\mathrm{H})$ rating risks in the outbound cargo warehouse. In general, the risks are excessive weight, forklift drop, hit by the falling cargo, poor environment, Pinched by Unit Loading Device (ULD), crashed by cargo, fall from PCHS roller. The high risk $(\mathrm{H})$ can cause permanent disability or loss of working time, months to years. While to the cargo goods, it can cause damaged quite heavily, but the goods can be repaired (see Table 1).

Table 1 also shows that in the job of cargo sorting, the risk with high level $(\mathrm{H})$ is hit by the falling goods. The high-risk of the work of compiling goods is falling down from the high place $(160 \mathrm{~cm}-190 \mathrm{~cm})$. On pallet binding, the risks of works are pinched by stud/lock, crashed by the cargo and pinched by cargo's build up.

Table 2. Risk Level Matrix in The Cargo Inbound Warehouse

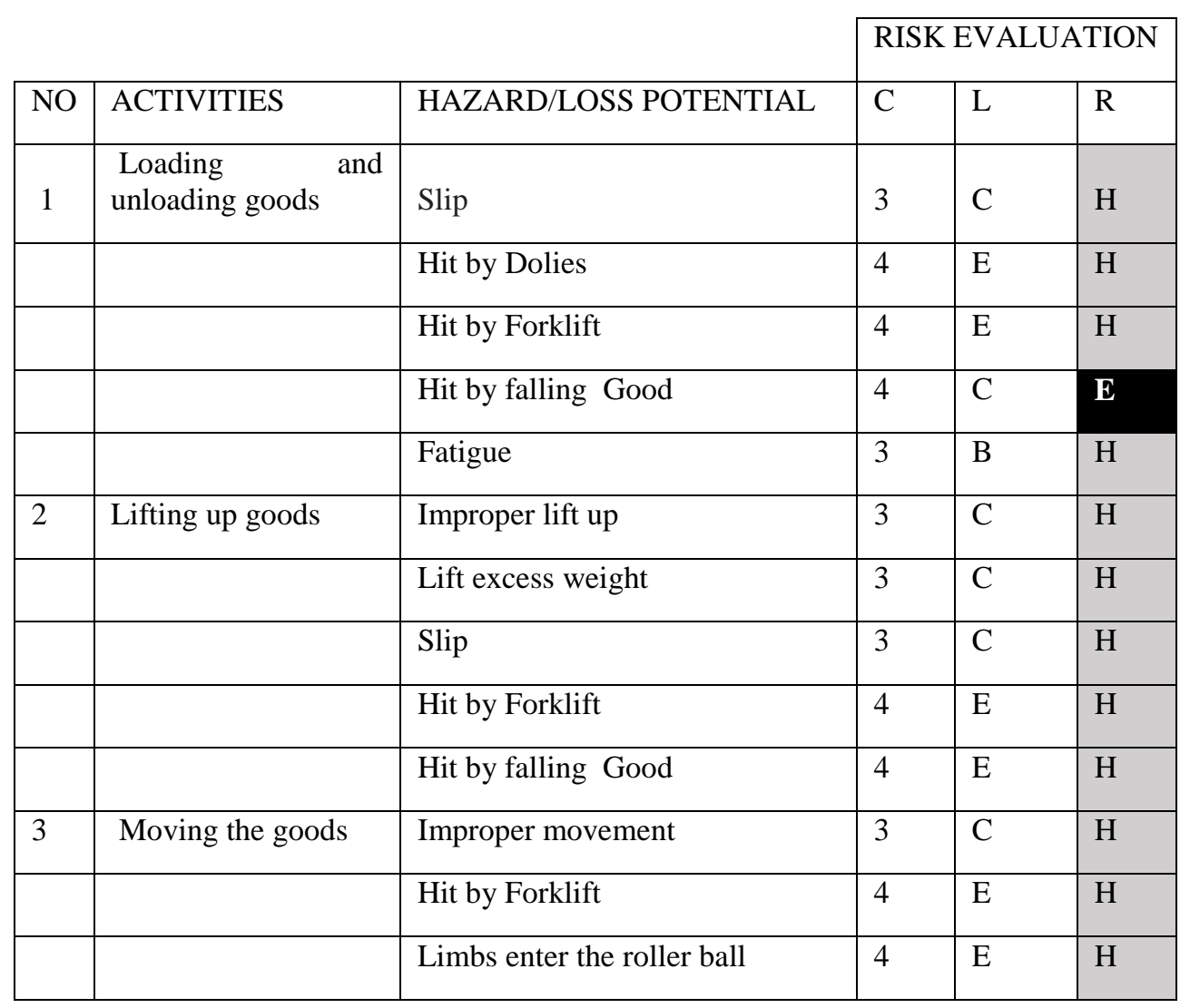


Table 2, Cont. Risk Level Matrix in The Cargo Inbound Warehouse

\begin{tabular}{|l|l|l|l|l|l|}
\hline & & Crashed by cargo & 4 & D & H \\
\hline & & Fall from the PCHS roller & 4 & D & H \\
\hline & & Fatigue & 3 & B & H \\
\hline 4 & Putting up the goods & hit by dollies & 4 & E & H \\
\hline & & hit by forklift & 4 & E & H \\
\hline & & Hit by falling Good & 4 & D & H \\
\hline & & Fatigue & 3 & B & H \\
\hline
\end{tabular}

The extreme risk (E) in the inbound warehouse is hit by falling goods of loading and unloading work in the breakdown area. While the risks that classified high $(\mathrm{H})$ are pinched by ULD, hit by Dollies, hit by the forklift, improper lifting, improper movement, excessive weight, slip, limbs enter the roller ball, fall from PCHS roller, and fatigue (see Table 2). In general, the job risks in outbound warehouses which classified as extreme and high risk are 21 risks, while the extreme and high risk in the inbound warehouse is 20 risks. Some other risks that have been identified using risk assessment, classified into the medium (M) category. Extreme or very high risk (E) that can cause death from work in outbound and inbound warehouses is the risk of falling goods or cargo. Therefore, the risk control programs are necessary to mitigate these risks to avoid causing fatal losses causing workers to suffer permanent injury or death.

\section{Improving Safety Behaviour}

The risk level analysis shows that the risks in outbound and inbound warehouses that must be noticed are hit by goods or cargo, crashed by forklifts and dollies. The ILO's risk control measures include elimination, substitution, engineering control, administrative control and the use of personal protective equipment (PPE). The cases in outbound and inbound warehouses that can be done as mitigation control programs are more to the administrative and use of PPE through active caring behavior.

Administratively, risk control steps can be done by setting a more optimal working time so that the fatigue condition can be reduced and socialization 
of Standard Operating Procedure (SOP) and safety procedure. Meanwhile, it is not urgent to do engineering control because existing equipment is still sufficient with warehouse capacity and workload during normal conditions. However, under certain conditions such as peak season, more effective arrangements are required so that workers do not perform unsafe acts due to lack of equipment.

Mitigation control should be followed by the monitoring activities to analyze the outcome of the programs. The process should be reviewed periodically so that potential new hazards or risks can be identified and controlled properly. The process should be implemented consistently by the workers and fully supported by the management as policymakers. Moreover, to improve the safety behavior or active caring behavior requires more than mitigation control. It will be effective if the management can employ the BehaviourBased Safety (BBS) approach. The BBS concept aims to change unsafe behavior to safe behavior and eliminate the occurring of accident in the workplace. The steps of BBS implementation can be divided into 4 main stages, namely, identify, observation, intervene, review and monitoring (Ismail et al., 2012). BBS is not only applicable to the construction industry but also other industries (Chen \& Tian, 2012).

The BBS approach will stimulate the active caring behavior and make workers remind each other when unsafe behaviour occurs, including reminding each other to use PPE. The BBS approach is not merely grown through punishment and rewards policies but from safety culture within organization. The punishment and rewards often result in two unintended consequences; 1) making employees reluctant to report minor incidents and near misses; 2) employees are not willing to honestly discuss the factors leading to the accident. The effect of punishment is immediate but sometime artificial, because it makes the workers only following procedures when the supervisor or manager is near them (McSween, 2003). The utilization of social recognition and motivating to conduct safety behavior will create more positive impact to alter normal norms of safety within the group than applying 
discipline through punishment(Cooper, 2001). Such behaviour will make the workers proactive more to control safety behavior or unsafe behavior and they can set target independently in their safety programs.

One of BBS principle is encouraging the workers to experience their own processes and provide them opportunities to choose. In the BBS, socialization and teaching procedures should be implemented using the principles. In addition, the management must ensure that SOPs are understandable to workers and easily applied, not just copy from international standards without proper adjustment. SOPs need to be updated and adjusted to working conditions and workloads, especially those related to extreme and high risks. The socialization and coaching of safety management system should be executed periodically. Some training to improve the safety behaviour in the warehouse that recommended are as follow; 1) training on the proper work procedure; 2) basic safety training; 3) training on dangerous goods handling (DG).

\section{Conclusion}

The risk level of activities in outbound and inbound warehouses is essentially similar. But each type of work has an extreme and high risk level that is different from one another due to the variety of the work environment, handling, and nature of the work. The mitigation control programs should be implemented to reduce the level of risk in the airport warehouses which include the administrative control and increased awareness of workers in using personal protective equipment (PPE). To improve the safety behavior, the management should consider employing the Behaviour-Based Safety (BBS) approach to create active caring behaviour among the workers. The active caring behaviour will make the workers perform their jobs with full awareness and behave safely without excessive pressure from rules or regulations.

\section{References}

Agushinta, L., Anggun, R., \& Wijaya, K. (2016). Pengaruh Penerapan Kesehatan dan Keselamatan Kerja Terhadap Kecelakaan Kerja 
Karyawan. JMBTL, 2(2), 287-295.

Cecchini, M., Bedini, R., Mosetti, D., Marino, S., \& Stasi, S. (2017). Safety Knowledge and Changing Behavior in Agricultural Workers: An Assessment Model Applied in Central Italy. Journal Safety and Health at Work, 1-8. https://doi.org/10.1016/j.shaw.2017.07.009

Chen, D., \& Tian, H. (2012). Behavior Based Safety for Accidents Prevention and Positive Study in China Construction Project. In Procedia Engineering (Vol. 43, pp. 528-534). https://doi.org/10.1016/j.proeng.2012.08.092

Cooper, D. (2001). Improving Safety Culture: A Practical Guide. Hull: Applied Behavioural Sciences.

DeVault, T. L., Blackwell, B. F., Seamans, T. W., \& Jerrold. (2016). Identification of off airport interspecific avian hazards to aircraft. The Journal of Willdlife Management, 80(4), 746-752.

Gautam, D. ;ChamlagainDeepak. (2015). Seismic hazard and liquefaction potential analysis of the Tribhuvan International Airport. In Journal of Nepal Geological Society (Vol. 48, p. 90).

Hou, W. B. L. C. H. J. (2016). Risk analysis of low-cost airline's entry aircraft from Southeast Asia at Qingdao airport. Chinese Journal of Frontier Health and Quarantine, 4.

International Civil Aviation Organization, I. (2013). Safety Management Manual ( SMM ).

International Labour Organization. (2013). Keselamatan dan Kesehatan Kerja Keselamatan dan Kesehatan Sarana untuk Produktivitas.

Ismail, F., Hashim, A. E., Zuriea, W., Ismail, W., Kamarudin, H., \& Baharom, Z. A. (2012). Behaviour Based Approach for Quality and Safety Environment Improvement : Malaysian Experience in the Oil and Gas Industry. In Procedia - Social and Behavioral Sciences (Vol. 35, pp. 586-594). https://doi.org/10.1016/j.sbspro.2012.02.125

Kania, D. D., Hanifah, \& Probo, E. (2016). Analisis Faktor Budaya Keselamatan dan Kesehatan Kerja (K3) Pada Penanganan Kargo Di Bandara Soekarno Hatta International Airport. JMTranslog, 3(1), 1-13.

Komisi Nasional Keselamatan Transportasi, K. (2016). Data Investigasi Penerbangan Tahun 2010-2016. Jakarta: KNKT.

Lee, W.-K. (2006). Risk assessment modeling in aviation safety management. Journal of Air Transport Management, 12(5), 267-273. https://doi.org/10.1016/j.jairtraman.2006.07.007

McSween, T. E. (2003). Value-Based Safety Process. New Jersey: John Wiley \& Sons.

Melissa, A. C., Tinggi, S., Transportasi, M., Suharno, H., Islam, U., Yusuf, S., ... Transportasi, M. (2017). Penerapan Safety Management System Dan Kompetensi Pemandu Lalu Lintas Penerbangan. JMTranslog, 4(1), 89-100.

Ostrowska, M., \& Mazur, S. (2015). Diversified Risk Management. Procedia Economics and Finance, 23(October 2014), 615-621. https://doi.org/10.1016/S2212-5671(15)00370-6

Riyadina, W. (2007). Kecelakaan Kerja dan Cedera yang Dialami oleh 
Pekerja di Kawasan Industri Pulo Gadung Jakarta. Journal Makara, 11(1), 25-31.

Sari, M., \& Artanti, D. (2015). Airport Ramp Risk Analysis at Halim Perdanakusuma. Journal Manajemen Transportasi Dan Logistik, 2(3), 275-286.

Shafieezadeh, Abdollah ; Cha, Eun J; Ellingwood, B. R. (2015). A decision framework for managing risk to airports from terrorist attack. Journal Risk Analysis, 33(2), 292-306.

Stewart, Mark; Mueller, J. (2013). Terrorism Risks and Cost-Benefit Analysis of Aviation Security. Journal Risk Analysis, 33(5), 893-908. https://doi.org/10.1111/j.1539-6924.2012.01905.x

Stewart, Mark; Mueller, J. (2014). A risk and cost-benefit analysis of police counter-terrorism operations at Australian airports. Journal of Policing, Intelligence and Counter Terrorism, 9(2), 98-116.

Susanthi, N. I., \& Seruni, I. P. (2016). Pengaruh pelatihan dan kesehatan keselamatan kerja terhadap kinerja karyawan pt jasa angkasa semesta. JMBTL, 2(3), 448-459.

Veland, H., \& Aven, T. (2015). Improving the risk assessments of critical operations to better reflect uncertainties and the unforeseen. Journal Safety Science, 79, 206-212. https://doi.org/10.1016/j.ssci.2015.06.012

Zin, S. M., \& Ismail, F. (2012). Employers 'Behavioural Safety Compliance Factors toward Occupational, Safety and Health Improvement in the Construction Industry. In Procedia - Social and Behavioral SciencesS (Vol. 36, pp. 742-751). https://doi.org/10.1016/j.sbspro.2012.03.081

Website

Australian Standard, Risk Management, 2004 : http://www.schleupen.de/content/schleupen/schleupen013223/A.4.1. 4 _Australia_and_New_Zealand_Methodology_AS_NZ\%25204360 1999.pdf[10 November 2011]

OSHA 3071,2002, Job Hazard Analysis. http://www.osha.gov [20 Dec 2011]

http://www.bpjsketenagakerjaan.go.id/berita/5769/Jumlah-kecelakaan-kerjadi-Indonesiamasih-tinggi.html [24 Oktober 2017] 